\title{
Meddelelser fra Grundtvig-Selskabet
}

\author{
Jes Fabricius Møller
}

Årsmødet 2018 havde højskolernes 175-års jubilæum som tema. Det foregik den 29. november i Vartovs store sal. Jes Fabricius Møller talte om Grundtvigs betydning og især hans indirekte betydning. Hans Henrik Hjermitslev gav et rids af udviklingen i højskolernes idégrundlag i det 20. århundrede, og hvordan Grundtvigs tanker om livsoplysning og historisk-poetisk dannelse blev løbende nyfortolket og fra 1970'erne nogle steder kastet på møddingen til fordel for new age-selvudvikling, ideer om socialistisk samfundsomvæltning og senest åndløs eliteidræt. Rasmus Kolby Rahbek belyste, hvordan grundtvigske nøglebegreber som livsoplysning, det historisk-poetiske, demokratisk dannelse og forpligtende fællesskaber bliver forstået af elever og lærere på højskolerne i dag. Fremmødet var meget tilfredsstillende, og diskussionen god.

Ved den efterfølgende generalforsamling skete der ingen ændringer i styrelsens sammensætning, dog blev Henrik Yde suppleant. På styrelsens foranledning vedtog generalforsamlingen en vedtægtsændring, således at $\$ 11$ fremover lyder: "Regnskabet følger kalenderåret. Det revideres af en revisor, som vælges af årsmødet. Genvalg kan finde sted.” At selskabet ikke længere skal bekoste en registreret revisor, er en væsentlig lettelse på budgettet. Thorstein Balle blev valgt som revisor. I repræsentantskabet er der sket udskiftning, idet Theodor Jørgensen er afgået ved døden, mens Johannes Adamsen og Therese Bering Solten blev valgt ind. Ved et efterfølgende styrelsesmøde konstituerede styrelsen sig med Jes Fabricius Møller som formand, Ingrid Ank som næstformand, Anders Holm som sekretær og Hans Henrik Hjermitslev som kasserer.

Endnu engang lykkedes det den omhyggelige og ihærdige redaktion af Grundtvig-Studier at sende et læseværdigt årsskrift på gaden med to fag- 
fællebedømte artikler og flere småstykker og anmeldelser. Styrelsen takker redaktionen for det meget store arbejde, der er blevet lagt $\mathrm{i}$ at fastholde årsskriftet som platform for publicering af den nyeste Grundtvigforskning og samtidig gøre det læseværdigt for en bredere kreds.

Igen i år bidrog selskabet til planlægningen af fejringen af Grundtvigs fødselsdag i Vartov, hvor der var arrangement for børn, Grundtvigbyvandring ved Ingrid Ank og mini-seminar om Niels og Joakim Skovgaard med oplæg af Kathrine Svanum Andersen og Rasmus Jensen.

Selskabet bidrog til Foreningen af Folkehøjskoler i Danmarks International Folk High School Summit, 23.-28. september 2019, hvor selskabets styrelse stod for oplæg om Grundtvig og folkehøjskolernes historie på Grundtvigs Højskole i Hillerød samt byvandring i Grundtvigs København og besøg i Grundtvigs Mindestuer i Udby.

Ved indledningen af finanslovsforhandlingerne i efteråret 2019 stod det klart, at regeringen i overensstemmelse med det erklærede ønske om at omprioritere forskningsmidler til fordel for den grønne omstilling ikke havde til hensigt at forlænge bevillingen til Grundtvig-Centeret. Det måtte der naturligvis reageres på, og efter at oplysningen om denne prioritering blev videreformidlet til Kristeligt Dagblads redaktion, bragte avisen historien på forsiden den 31. oktober og som tophistorie flere af de følgende dage, og det førte til, at bevillingen til centeret igen fandt plads i finanslovsudkastet. Interessen for Grundtvig er heldigvis også blandt politikerne usvækket. Styrelsen takker alle, der har bistået Grundtvig-Selskabet i dets virke, samt selskabets knap 200 medlemmer for deres støtte til Grundtvig-Selskabets arbejde med "at fremme studiet af N.F.S. Grundtvig, hans virke og hans stilling i åndslivet i og uden for Danmark”. 